\title{
Detection of a Novel Reassortant H9N9 Avian Influenza Virus in Free-Range Ducks in Bangladesh
}

\author{
Rabeh El-Shesheny ${ }^{1,2}{ }^{-}$, Jasmine C. M. Turner ${ }^{1}$, David Walker ${ }^{1}$, John Franks ${ }^{1}$, Patrick Seiler ${ }^{1}$, Subrata Barman ${ }^{1}$, \\ Mohammed M. Feeroz ${ }^{3}$, Md Kamrul Hasan ${ }^{3}$, Sharmin Akhtar ${ }^{3}$, Nabanita Mukherjee ${ }^{1}$, Lisa Kercher ${ }^{1}$, \\ Pamela McKenzie ${ }^{1}$, Robert G. Webster ${ }^{1}$ and Richard J. Webby ${ }^{1, *(D)}$ \\ 1 Department of Infectious Diseases, St. Jude Children's Research Hospital, Memphis, TN 38105, USA; \\ rabeh.elshesheny@stjude.org (R.E.-S.); jasmine.turner@stjude.org (J.C.M.T.); david.walker@stjude.org (D.W.); \\ john.franks@stjude.org (J.F.); jon.seiler@stjude.org (P.S.); subrata.barman@stjude.org (S.B.); \\ nabanita.mukherjee@stjude.org (N.M.); lisa.kercher@stjude.org (L.K.); pamela.mckenzie@stjude.org (P.M.); \\ Robert.Webster@STJUDE.ORG (R.G.W.) \\ 2 Center of Scientific Excellence for Influenza Viruses, National Research Centre, Giza 12622, Egypt \\ 3 Department of Zoology, Jahangirnagar University, Savar 1342, Bangladesh; feerozmm@yahoo.com (M.M.F.); \\ mkhasan@ucdavis.edu (M.K.H.); sarumpazoolju@gmail.com (S.A.) \\ * Correspondence: richard.webby@stjude.org
}

\section{check for}

updates

Citation: El-Shesheny, R.; Turner, J.C.M.; Walker, D.; Franks, J.; Seiler, P.; Barman, S.; Feeroz, M.M.; Hasan, M.K.; Akhtar, S.; Mukherjee, N.; et al. Detection of a Novel Reassortant H9N9 Avian Influenza Virus in Free-Range Ducks in Bangladesh. Viruses 2021, 13, 2357. https:// doi.org/10.3390/v13122357

Academic Editors: Gregory Tannock and Hyunsuh Kim

Received: 21 October 2021

Accepted: 20 November 2021

Published: 24 November 2021

Publisher's Note: MDPI stays neutral with regard to jurisdictional claims in published maps and institutional affiliations.

Copyright: (C) 2021 by the authors. Licensee MDPI, Basel, Switzerland. This article is an open access article distributed under the terms and conditions of the Creative Commons Attribution (CC BY) license (https:// creativecommons.org/licenses/by/ $4.0 /)$.

\begin{abstract}
Wild aquatic birds are the primary natural reservoir for influenza A viruses (IAVs). In this study, an A(H9N9) influenza A virus (A/duck/Bangladesh/44493/2020) was identified via routine surveillance in free-range domestic ducks in Bangladesh. Phylogenetic analysis of hemagglutinin showed that the H9N9 virus belonged to the Y439-like lineage. The HA gene had the highest nucleotide identity to A/Bean Goose (Anser fabalis)/South Korea/KNU 2019-16/2019 (H9N2). The other seven gene segments clustered within the Eurasian lineage.
\end{abstract}

Keywords: avian influenza; free-range ducks; Bangladesh

\section{Introduction}

Influenza A viruses (IAVs) threaten the health of humans and animals worldwide. Avian influenza viruses (AIVs) are widespread in nature, with waterfowl serving as the primary reservoir from which transmission of influenza subtypes to domestic poultry occurs [1]. IAVs are classified based on surface glycoproteins hemagglutinin (HA) and neuraminidase (NA), with 18 HA subtypes (H1-H18) and 11 NA subtypes (N1-N11). To date, many combinations of HA (H1-16) and NA (N1-9) subtypes have been identified in wild birds.

Reassortment represents a major mechanism supporting the emergence and evolution of IAVs. Domestic ducks can perpetuate many AIV subtypes via asymptomatic shedding, which plays an important role in the epidemiology, dissemination, and reassortment of lowpathogenic avian influenza (LPAI) viruses [1]. Specifically, free-range ducks are considered to be a primary link for bidirectional transmission of AIVs between wild and domestic birds providing the interface that play role for AIV reassortment. Epidemiological data indicated that recent zoonotic H7N9 and H10N8 infections were caused by viruses that originated in domestic ducks and spread to chickens [2-4]. Our previous studies have also shown the role of free-range ducks in the spread of influenza viruses to other species in live-poultry markets in Bangladesh [5,6].

Highly pathogenic AIV (H5N1) was initially introduced into Bangladesh in 2007 and has since become endemic in poultry. Multiple clades of H5N1 Gs/Gd lineage viruses (Clades 2.2.2, 2.3.4.2, and 2.3.2.1a) were identified in Bangladeshi live-poultry markets (LPMs) $[7,8]$. Due to the continued circulation of H5N1 Gs/Gd lineage in LPMs along with LPAI viruses, reassortment between HPAI H5N1 and LPAI viruses was detected in live-poultry markets in Bangladesh [9]. A recent study detected H5Nx reassortants that 
had high virulence in mice and chickens but limited transmission between ferrets [10]. Adaptions and continuous reassortments can not only facilitate the spread of the IAVs but can also contribute to increased levels of genetic diversity.

H9N2 AIVs were widespread in poultry globally and sporadically detected in humans. As of October 2021, a total of 82 laboratory-confirmed human cases with H9N2 infections have been reported [11]. Based on the phylogenetic clustering of HA genes, H9N2 viruses can be divided to three main lineages: G1-like, Y280-like/BJ/94-like, and Y439-like. The G1-like lineage viruses circulate in Asia, the Middle East, and Africa. The Y280-like/BJ/94like lineage viruses circulate in China. The Y439 lineage viruses circulate endemically in poultry in South Korea and have been isolated from wild birds and poultry in Europe, Asia, and South Africa [12]. H9N2 AIVs have been confirmed as donors of internal genes to AIVs with pandemic potential such as H5Nx, H7N9, and H10N8 AIVs, posing an enormous threat to both human and animal health.

Active surveillance for AIV in Bangladesh during the past decade led to the identification of several influenza virus subtypes, most abundantly H9N2. The first reported detection of H9N2 viruses of the G1 lineage in Bangladesh occurred in 2006 in a commercial breeder. Continued circulation of H9N2 viruses in Bangladesh have allowed for the accumulation of molecular markers that enhance viral replication in mammals [13]. Human infections with influenza H9N2 viruses were first detected in Bangladesh in 2011. The continued presence of these viruses at the human-poultry interface provides opportunities for H9N2 AIVs to donate significant genetic material to emerging zoonotic viruses, threatening both human health and the poultry industry. Here, we analyzed the phylogenetic and genetic properties of the newly identified reassortant H9N9 isolate from free-range domestic ducks in Tanguar Haor.

\section{Materials and Methods}

\subsection{Sampling and Surveillance for AIVs}

Active surveillance of poultry has been conducted in Bangladesh through collaborative efforts of the Center of Excellence for Influenza Research and Surveillance at St. Jude (Memphis, TN, USA) and Jahangirnagar University (Dhaka, Bangladesh) since 2008 in LBMs and since 2015 in Tanguar Haor, a wetland area in northeastern Bangladesh where local domestic ducks are reared and where birds winter during the migratory season. Swab and fecal samples were collected from various species of wild birds and from free-range ducks from the Tanguar Haor area. Samples were collected as previously described $[5,14,15]$. Samples were stored at $\sim 4{ }^{\circ} \mathrm{C}$ in the field, moved to liquid nitrogen within one week of collection, and then shipped to the biosafety level 3 facilities of St. Jude Children's Research Hospital in Memphis, TN, USA, for further analysis.

\subsection{Virus Isolation from Samples}

Samples were screened for the presence of AIV by real-time RT-PCR targeting the M gene by using TaqMan probes, 4x Fast Virus RT-PCR kit (Life Technologies, Rockville, MD, USA), in ABI 7500 Fast PCR. Primer and probe sequences are as follows: forward primer: $5^{\prime}-$ GACCRATCCTGTCACCTCTGAC-3', reverse primer: 5'- AGGGCATTYTGGACAAAKCGTCTA-3', probe: 5'-6FAM-TGCAGTCCTCGCTCACTGGGCACG-TAMRA-3'. Samples were classified as positive with a $\mathrm{Ct}$ value $\leq 36$. All positive samples were inoculated in 10-day-old embryonated chicken eggs for virus isolation. Isolated viruses were incubated at $38{ }^{\circ} \mathrm{C}$ for $72 \mathrm{~h}$ and stored at $4{ }^{\circ} \mathrm{C}$ overnight. Hemagglutination assays (HA) of the allantoic fluids from the inoculated eggs were performed to screen for IAV according to World Health Organization (WHO) and World Organization for Animal Health (OIE) protocols [16,17].

\subsection{Subtype Detection and Sequencing}

This step was performed as previously described [10]. Briefly, viral RNA was extracted from allantoic fluid before conventional two-step reverse transcription-PCR was performed 
by using a SuperScript IV first-strand synthesis kit (Invitrogen) and the Uni12 influenza primer. Then, Phusion high-fidelity DNA polymerase (New England Biolabs, Ipswich, MA, USA) and Uni12/13 primers were used for multiplex PCR of all eight gene segments, and PCR products were purified. The staff of the Hartwell Center at St. Jude Children's Research Hospital prepared the DNA libraries, which were then pooled and sequenced via $150 \mathrm{bp}$ paired end reads by using an Illumina MiSeq personal genome sequencer. The sequencing reads were analyzed by using CLC Genomics Workbench, version 20 (CLC Bio, Qiagen, Hilden, Germany).

\subsection{Phylogenetic Analysis}

As in our previous study, all reference sequences were obtained from the NCBI Influenza Virus Resource (https://www.ncbi.nlm.nih.gov/genbank/) and GISAID (http: / / www.gisaid.org), accessed on 15 April 2021, and BLAST homology analysis of nucleic acids was performed on the NCBI and/or GISAID website. DNA Lasergene 15 and BioEdit7.0 [18] were used for multiple sequence alignment and genomic signature analysis using the ClustalW algorithm [19]. MEGA 7 was used for the phylogenetic tree reconstruction by applying the neighbor-joining method with Kimura's two-parameter distance model and 1000 bootstrap replicates [20].

\section{Results and Discussion}

Active surveillance of poultry has been conducted in Bangladesh and several influenza virus subtypes, including highly pathogenic $\mathrm{H} 5 \mathrm{Nx}$ and $\mathrm{H} 9 \mathrm{~N} 2$ and other low pathogenic avian influenza viruses, have been isolated [5,6,9,10,15,21]. On 22 February 2020, AIV virus was isolated from the swab sample of a Khaki Campbell duck and confirmed via sequencing to be an H9N9 virus. We performed deep sequencing to determine the complete genome sequence of the newly identified H9N9 virus (GenBank accession numbers MW749817.1 to MW749823.1).

We studied the genetic relationship between the H9N9 virus, other viruses isolated from Bangladesh, and other viruses available in GenBank. The HA genes shared 97.62\% nucleotide identity with A/Bean Goose (Anser fabalis)/South Korea/KNU 201916/2019 (H9N2) (Table 1), and the NA gene shared 98.47\% nucleotide identity with A/Anas platyrhynchos/South Korea/JB31-96/2019 (H11N9). Other internal genes shared high nucleotide identities with viruses isolated from Tanguar Haor, Bangladesh, during the same season (Table 1).

Table 1. Comparison of nucleotide sequence identities of the eight influenza A virus (IAV) gene sequences for the virus isolated in this study (A/duck/Bangladesh/44493/2020 (H9N9)) and nearest virus homologs.

\begin{tabular}{cccc}
\hline Gene & Accession No. & Virus & \% Identity \\
\hline PB2 & MT020147.1 & A/duck/Mongolia/926/2019(H5N3) & 99.1 \\
& MW749040.1 & A/duck/Bangladesh/44478/2020(H10N9) & 100 \\
PB1 & MN208036.1 & A/northern shoveler/Egypt/MB-D-690C/2016(H7N3) & 99.63 \\
& MW749040.1 & A/duck/Bangladesh/44478/2020(H10N9) & 99.96 \\
PA & MW188628.1 & A/duck/Mongolia/447/2018(H4N6) & 99.1 \\
& MW749040.1 & A/duck/Bangladesh/44478/2020(H10N9) & 100 \\
HA & EPI_ISL_418175 & A/Bean Goose(Anser fabalis)/South Korea/KNU 2019-16/2019(H9N2) & 97.62 \\
NP & MN208011.1 & A/teal/Egypt/MB-D-487OP/2016(H7N3) & 100 \\
& MW749040.1 & A/duck/Bangladesh/44478/2020(H10N9) & 98.47 \\
NA & MW116667.1 & A/Anas platyrhynchos/South Korea/JB31-96/2019(H11N9) & 99.21 \\
M & MW188600.1 & A/duck/Mongolia/345/2018(H4N6) & 99.80 \\
& MW749040.1 & A/duck/Bangladesh/44478/2020(H10N9) & 99.77 \\
NS & MT020282.1 & A/duck/Mongolia/961/2019(H3N8) & 100 \\
& MW466161.1 & A/environment/Bangladesh/42635/2020(H10N7) & \\
\hline
\end{tabular}

* PB2, basic polymerase 2; PB1, basic polymerase 1; PA, acidic polymerase; HA, hemagglutinin; NP, nucleoprotein; NA, neuraminidase; MP, matrix protein; NS, nonstructural protein. ${ }^{\dagger}$ Nearest virus homologs to A/duck/Bangladesh/44493/2020 (H9N9) isolated from Tanguar Haor wetlands in Bangladesh. 
To better understand the genetic relationship of the H9N9 virus to other influenza viruses, we conducted phylogenic analyses. The sequences of these viruses are available in GenBank and the GISAID database (https: / / www.gisaid.org, accessed on 15 April 2021). This analysis revealed that the HA sequence clustered with the Y439-like lineage and was most closely related to those of H9N2 viruses isolated from South Korea in 2019-2020 (Figure 1). The amino acid sequence of the HA of the H9N9 virus included a single arginine residue at the cleavage site of HA1 and HA2 (PAASDR $\downarrow$ GLF), indicating that it was a low pathogenic strain in the chicken host [22-24]. We examined the presence of N-linked glycosylation motifs by interrogating the proteins for $\mathrm{N}-(\mathrm{P}-[\mathrm{S} / \mathrm{T}]-\mathrm{P})$ motifs, which indicate potential N-linked glycosylation sites. We identified seven potential glycosylation sites at positions 29-31 (NTS), 141-143 (NVT), 218-220 (NRT), 298-300 (NTT), 305-307 (NIS), 492-494 (NGT), and 551-553 (NGS).

We evaluated residues known to impact receptor-binding preference because mutations conveying a preference for human-type receptors could enable zoonotic transmission. Our isolate harbored HA markers (198 E, 226Q, and 228G), suggesting more efficient binding to avian receptors than to human receptors [25]. However, the H9N9 virus had the I155T mutation, which plays an important role in binding the H9N2 virus to the human-type receptor [26].

Phylogenetic analysis of the H9N9 NA gene showed that it was most closely related to H11N9 AIVs isolated from South Korea in 2019 that belonged to the wider Eurasian lineage, also related to A/teal/Egypt/MB-D-621C/2016 (H7N9) (Figure 2). Additionally, the NA gene of H9N9 strain showed similarities with H11N9, H7N9, and H10N9 strains isolated from free-range ducks in Tanguar Haor in 2010, 2015, 2016, and 2017 [21]. This finding indicates that in Bangladesh, the NA genes may circulate between wild birds and free-range ducks. The N9 gene of the H9N9 isolate showed 93.5\% nucleotide identity with A/Anhui/1/2013(H7N9), which caused human infections in China, and clustered within a different group (Figure 2). Our isolates did not display oseltamivir resistance markers E119, H275, R293, and N295 (N1 numbering).

Phylogenetic analyses of the six internal genes (PB2, PB1, PA, NP, M, and NS) of the H9N9 isolate showed that it belonged to the Eurasian lineage (Figure 3). The E627K and D710N substitutions in the PB2 gene, which play an important role in the adaptation of AIVs to mammals [27], were not detected in our isolate. However, the PB2 amino acid substitutions L89V, G309D, and T339K, which increase replication in human lung epithelial cells and mice [28,29], were observed in the PB2 gene. The H9N9 isolate's PA contained amino acid substitutions (Table 2), including the PA-A515T mutation, which may be associated with adaptation to mammals [30]. The PB1-F2 protein was variable in length, with PB1-F2 of H9N9 isolate being 90-aa long. It also had the N66S mutation, which increases virulence, replication efficiency, and the antiviral response in mice [31].

No substitutions associated with antiviral resistance to the adamantanes were identified. Our analyses showed that NS1 protein of H9N9 contains amino acid substitutions P42S and V149A (Table 2), and these mutations were found to be associated with virulence and pathogenicity in mammals.

H9N9 virus is a rarely isolated subtype among IAV, most being isolated from wild birds from North America (Figure 4). The first detections were in 1988 from ruddy turnstone and laughing gull from Virginia and Delaware Bay, respectively: A/ruddy turnstone/Virginia/2297/1988 (H9N9) and A/laughing gull/Delaware/2971/1988 (H9N9). Through longitudinal surveillance in Delaware Bay, we detected this subtype in ruddy turnstones from 1988-2019 (Figure 4B) [49]. This subtype was detected in England and France before 2013 (Figure 4). H9N9 was detected in China in 2013; the HA closely clustered with the H9N2 strains circulating in China at the time, but the NA genes clustered with the H7N9 viruses [50]. This pattern suggests that the H9N9 virus isolated from China may have originated from reassortment of H9N2 viruses with H7N9 viruses within a domestic avian host. 


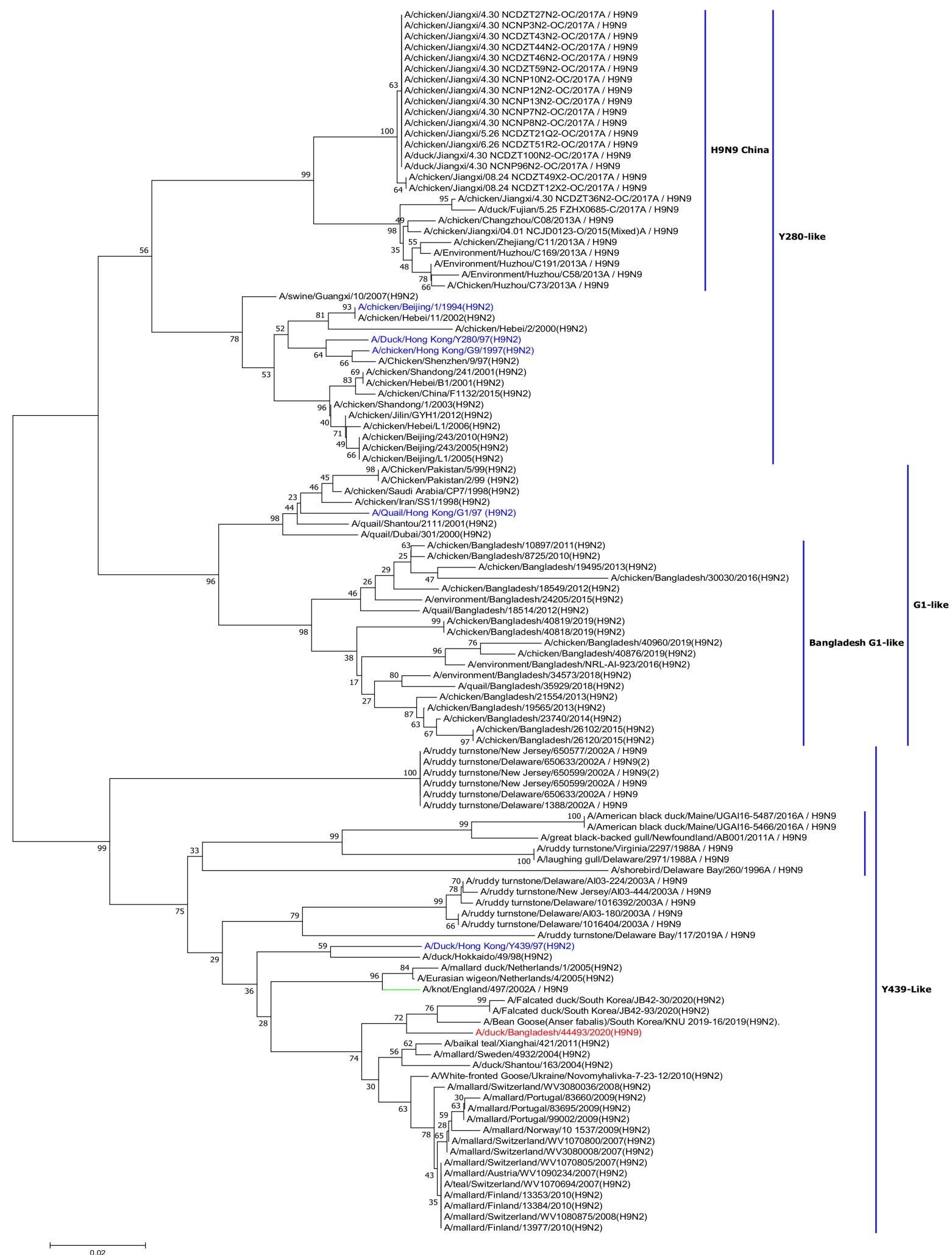

Figure 1. Phylogenetic tree of the HA gene. Phylogenetic analysis was performed using the neighbor-joining algorithm with the Kimura two-parameter model. The reliability of phylogenetic inference at each branch node was estimated by the bootstrap method with 1000 replications; evolutionary analyses were conducted in mega 7. The HA gene of H9N9 virus isolate in this study is marked in red and H9N2 reference strains are marked in blue. 


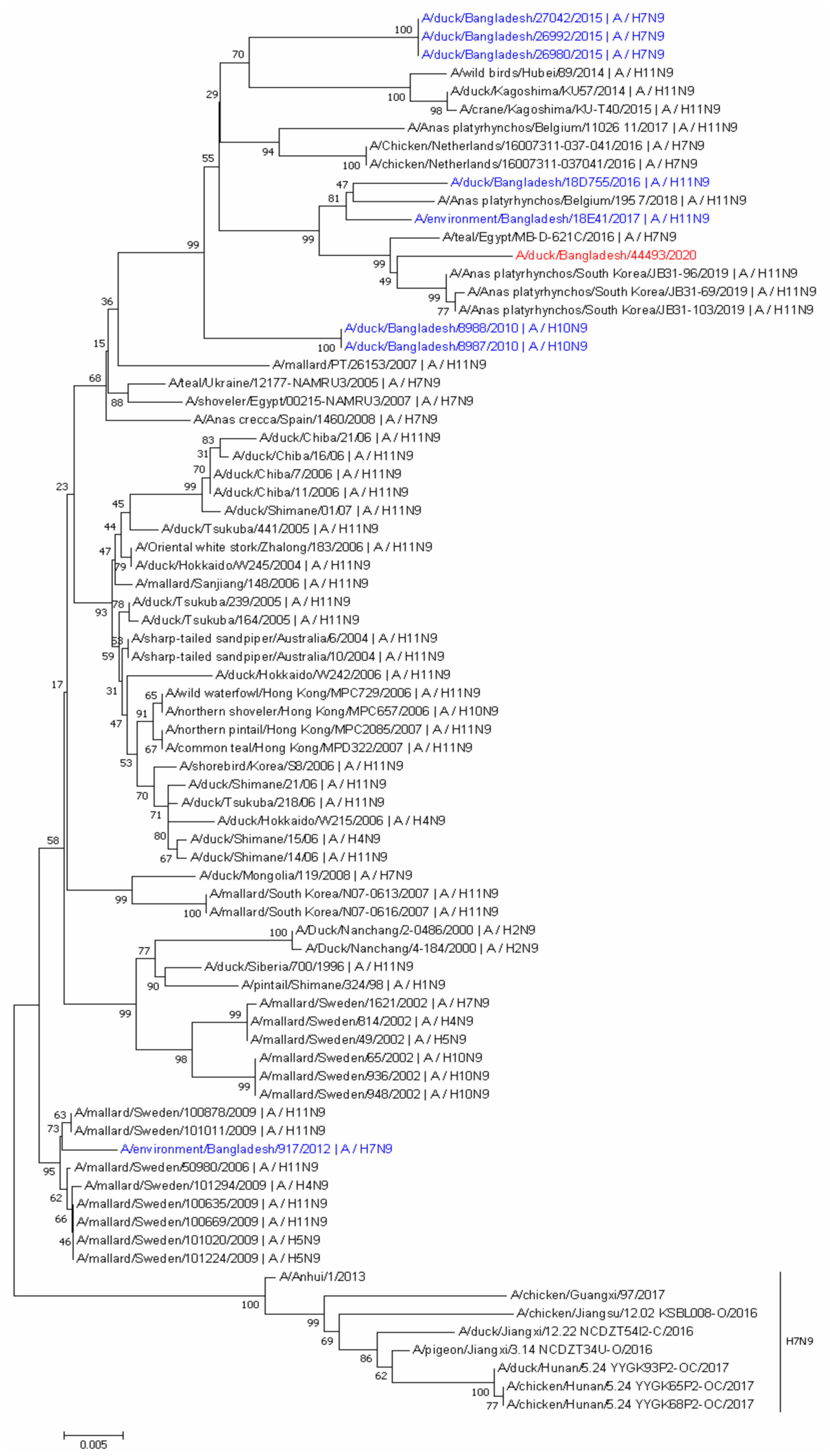

Figure 2. Phylogenetic tree of the NA gene. Phylogenetic analysis was performed using the neighborjoining algorithm with the Kimura two-parameter model. The reliability of phylogenetic inference at each branch node was estimated by the bootstrap method with 1000 replications; evolutionary analyses were conducted in mega 7. The NA gene of H9N9 virus isolate in this study is marked in red. N9 gene of viruses isolated from Tanguar Haor area in Bangladesh are marked in blue. 


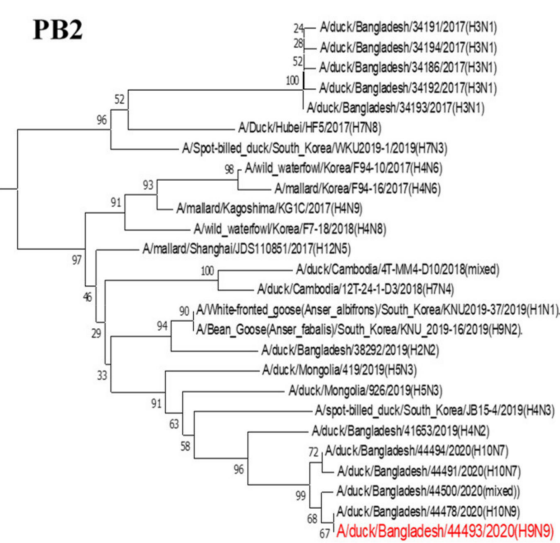

0.000

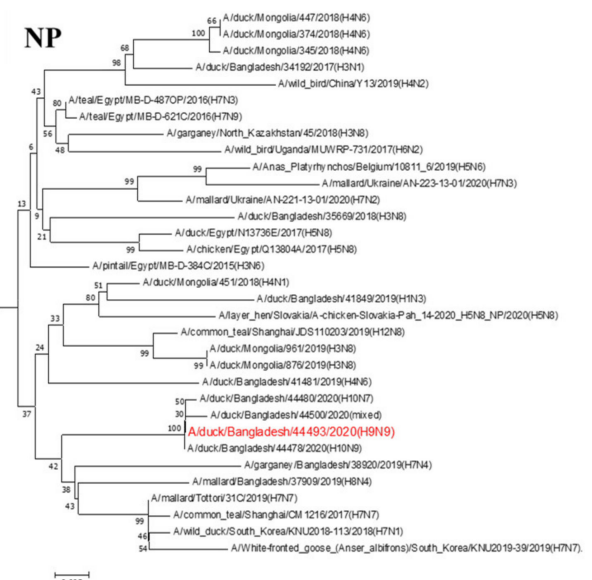

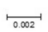

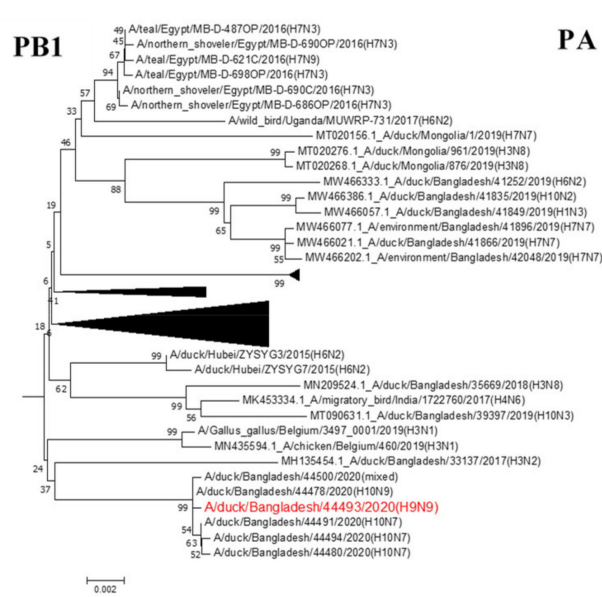

PA
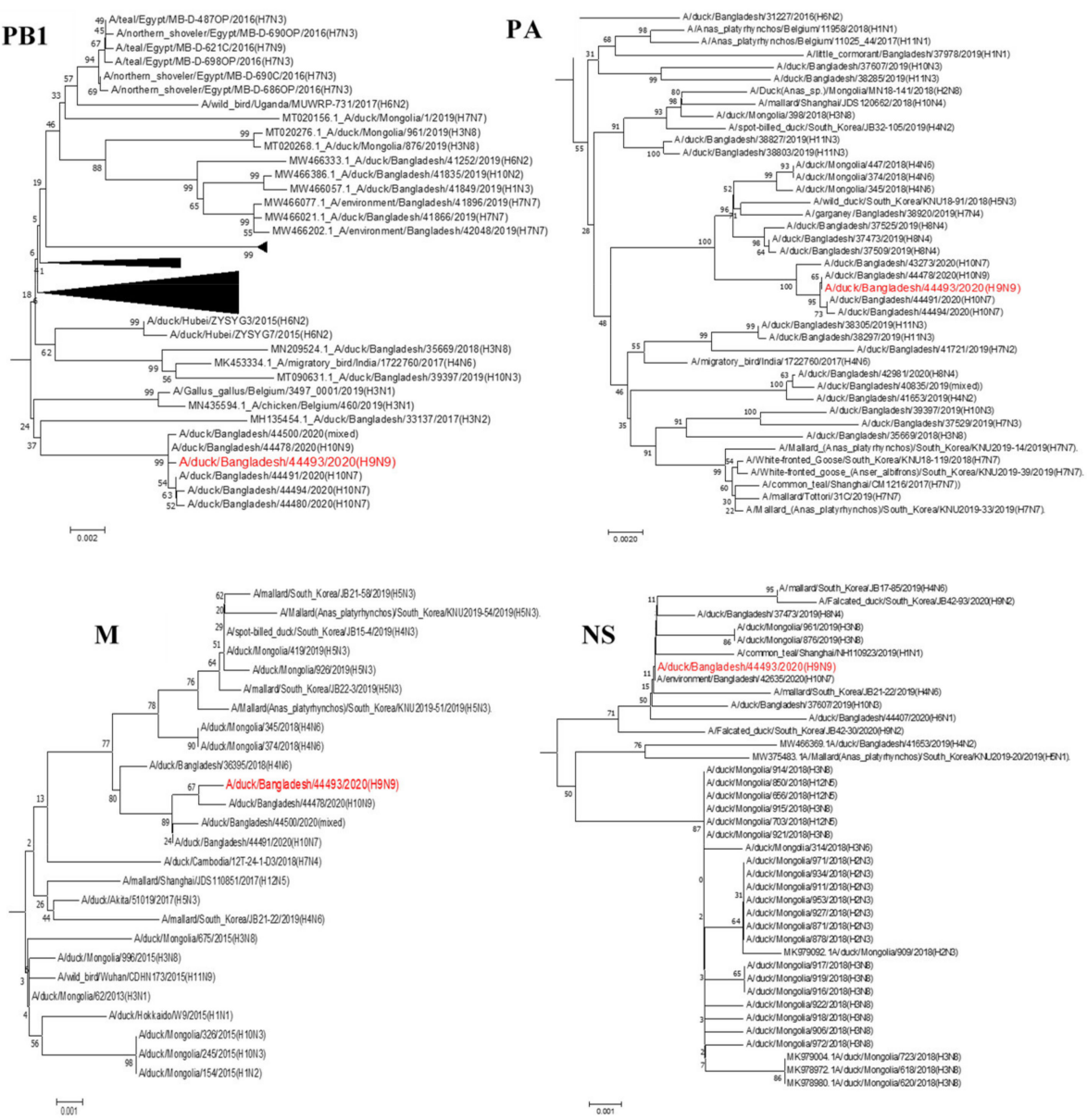

Figure 3. Phylogenetic trees of six internal genes of the isolated H9N9 virus. Phylogenetic trees were constructed for six internal gene segments using the limited homologous viruses. H9N9 virus isolate in this study is marked in red.

The phylogenetic trees of HA and NA indicate that the newly identified H9N9 is most genetically similar to H9N2 and H11N9 viruses isolated from South Korea rather than to Bangladeshi H9N2 viruses, suggesting that ancestors of this virus emerged among wild birds and were transmitted to Tanguar Haor's free-range ducks. Wild aquatic birds are considered to be natural reservoirs for AIVs and are vital for AIV to evolve, be maintained, and spread. Bangladesh is in the Central Asian flyway and near the Eastern Asian-Australian and Black Sea-Mediterranean flyways. It also serves as a stopover site for migratory birds. We previously showed that interactions between wild birds and ducks play a role in reassortments and emerging new strains [5,6]. Two scenarios exist for the genesis of this virus, that it was generated elsewhere and arrived in Bangladesh with bird movement or that it arose in Bangladesh through local reassortment. The phylogenetic relationships of the genes of this virus with LPAI viruses isolated from Bangladesh led us to favor the latter possibility.

Controlling AIVs in Bangladesh requires the integration of multiple strategies including vaccination, active surveillance, biosecurity, and improved awareness of producers and traders. HPAIV vaccination strategies were introduced in Bangladesh in 2012 and vaccination against $\mathrm{H} 9 \mathrm{~N} 2$ has recently been approved [51].

When different viruses co-circulate in the same area, novel reassortants with variable phenotypes can emerge. In our surveillance, we detected other LPAI viruses from domestic duck and/or free-range ducks and wild birds in the Tanguar Haor area in Bangladesh, raising concern about the potential for the emergence of reassortant viruses. Evaluating the biologic properties of the newly identified H9N9 virus is crucial for increased knowledge of these viruses' emergence and evolution. Such knowledge is vital to predict and fight potential pandemics that would threaten public health. 
Table 2. Assessment of molecular markers for zoonotic potential of the influenza A(H9N9) virus.

\begin{tabular}{|c|c|c|c|c|}
\hline Viral Protein & Amino Acid & $\begin{array}{c}\text { A/duck/Bangladesh/ } \\
44493 / 2020\end{array}$ & Functional Relevance & References \\
\hline \multirow{6}{*}{ PB2 } & E627K & $\mathrm{E}$ & Mammalian host adaptation & [32] \\
\hline & D701N & $\mathrm{D}$ & $\begin{array}{l}\text { Increase polymerase activity and viral } \\
\text { replication in mammalian cells }\end{array}$ & [33] \\
\hline & L89V & $\mathrm{V}$ & $\begin{array}{l}\text { Enhanced polymerase activity, increased } \\
\text { virulence in mice }\end{array}$ & [28] \\
\hline & G309D & $\mathrm{D}$ & $\begin{array}{l}\text { Enhanced polymerase activity, increased } \\
\text { virulence in mice }\end{array}$ & [28] \\
\hline & T339K & $\mathrm{K}$ & $\begin{array}{l}\text { Enhanced polymerase activity, increased } \\
\text { virulence in mice }\end{array}$ & [28] \\
\hline & A $588 \mathrm{~V}$ & A & Mammalian host adaptation & [34] \\
\hline PB1-F2 & N66S & S & $\begin{array}{l}\text { Increases virulence, replication efficiency, } \\
\text { and the antiviral response in mammals }\end{array}$ & {$[31,35]$} \\
\hline \multirow{3}{*}{ PA } & V100A & $\mathrm{V}$ & $\begin{array}{l}\text { Contributed to the virulence and } \\
\text { mammalian adaptation }\end{array}$ & \\
\hline & S409N & S & $\begin{array}{l}\text { Contributed to the virulence and } \\
\text { mammalian adaptation }\end{array}$ & [36] \\
\hline & A515T & $\mathrm{T}$ & $\begin{array}{l}\text { Increased polymerase activity, increased } \\
\text { virulence in mammals and birds }\end{array}$ & {$[30]$} \\
\hline \multirow{4}{*}{ HA } & E198D & E & Enhanced mammalian receptor binding & [37] \\
\hline & Q234L & Q & $\begin{array}{l}\text { Preferential binding to human Sialic acid } \\
\qquad \alpha 2-6 \text { receptor }\end{array}$ & {$[38,39]$} \\
\hline & G236S & G & $\begin{array}{l}\text { Preferential binding to human Sialic acid } \\
\qquad \alpha 2-6 \text { receptor }\end{array}$ & [38] \\
\hline & I155T & $\mathrm{T}$ & Enhanced mammalian receptor binding & {$[40]$} \\
\hline \multirow{4}{*}{ NA } & E119V & E & Oseltamivir resistance & [41] \\
\hline & $\mathrm{H} 275 \mathrm{Y}$ & $\mathrm{H}$ & Oseltamivir resistance & [41] \\
\hline & R293K & $\mathrm{R}$ & Oseltamivir resistance & [42] \\
\hline & N295S & $\mathrm{N}$ & Oseltamivir resistance & [41] \\
\hline \multirow{5}{*}{ M2 } & L26P & $\mathrm{L}$ & Reduced susceptibility to amantadine & {$[43,44]$} \\
\hline & V27A/I & $\mathrm{V}$ & Reduced susceptibility to amantadine & {$[43,44]$} \\
\hline & A30T & $\mathrm{A}$ & Reduced susceptibility to amantadine & {$[44,45]$} \\
\hline & S31N & S & Reduced susceptibility to amantadine & {$[44,45]$} \\
\hline & G34E & G & Reduced susceptibility to amantadine & {$[43]$} \\
\hline \multirow{3}{*}{ NS1 } & P42S & S & $\begin{array}{l}\text { Increased virulence and pathogenicity in } \\
\text { mammals }\end{array}$ & [46] \\
\hline & D92E & $\mathrm{D}$ & $\begin{array}{l}\text { Increased virulence and pathogenicity } \\
\text { in mammals }\end{array}$ & [47] \\
\hline & V149A & A & $\begin{array}{l}\text { Increased virulence and pathogenicity } \\
\text { in mammals }\end{array}$ & [48] \\
\hline
\end{tabular}




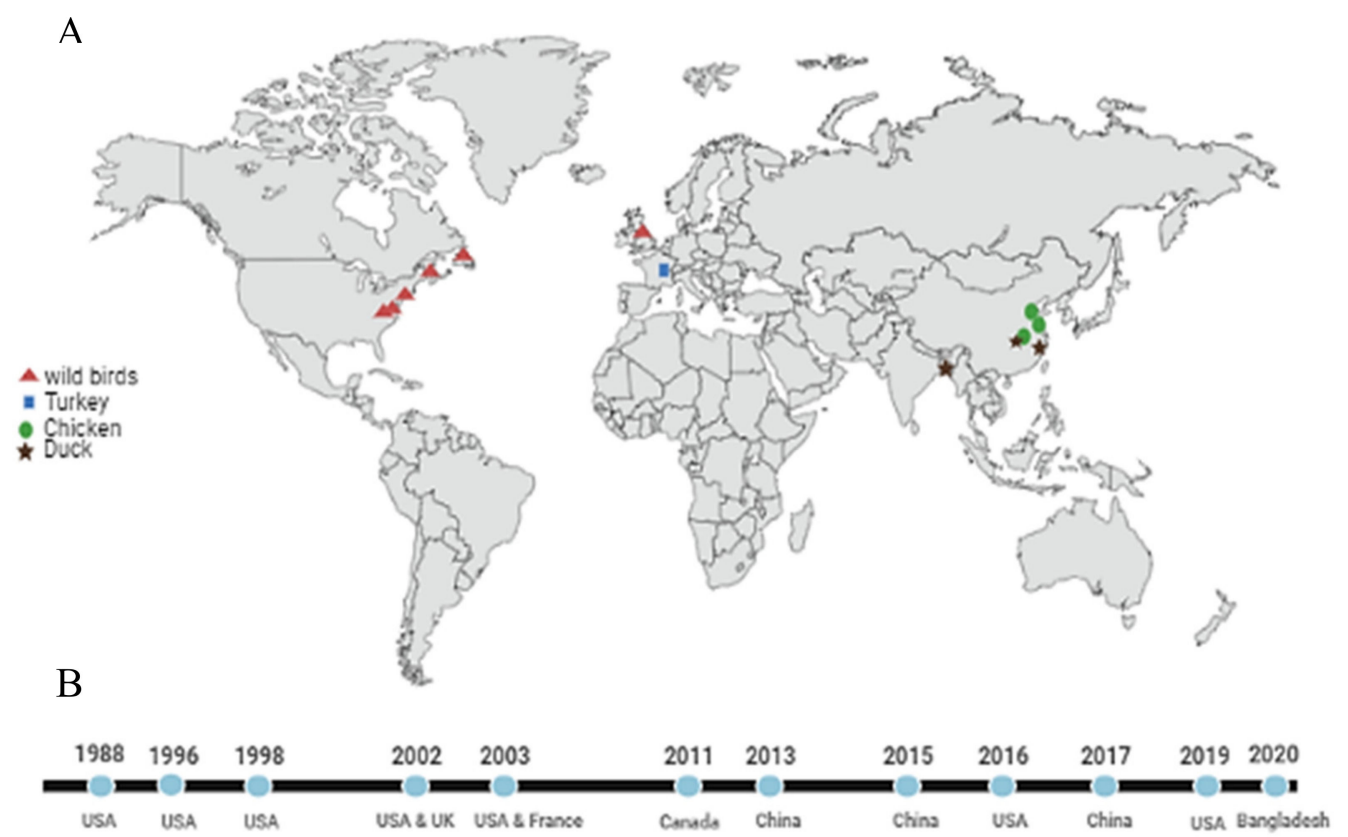

Figure 4. Emergence and distribution of H9N9 viruses from 1988 to 2020. (A) Distributions of H9N9 viruses in different countries and host range. (B) Detection timeline of H9N9 viruses.

Author Contributions: Conceptualization, R.E.-S., R.J.W. and R.G.W.; methodology, R.E.-S., J.F., J.C.M.T., P.S., D.W. and L.K.; formal analysis, R.E.-S., J.C.M.T. and S.B.; investigation, R.E.-S. and J.C.M.T.; data curation, R.E.-S.; reagents/materials/analysis tools, N.M., M.K.H., M.M.F., S.A. and P.M.; writing —original draft preparation, R.E.-S.; writing-review and editing, R.E.-S., J.C.M.T., L.K., R.J.W. and R.G.W.; supervision, R.J.W. and R.G.W.; funding acquisition, P.M. and R.J.W. All authors have read and agreed to the published version of the manuscript.

Funding: This work was funded by the National Institute of Allergy and Infectious Diseases, National Institutes of Health (CEIRS contract no. HHSN266200700006C), and American Lebanese Syrian Associated Charities (ALSAC). The content is solely the responsibility of the authors and does not necessarily represent the official views of the National Institutes of Health or ALSAC.

Institutional Review Board Statement: Not applicable.

Informed Consent Statement: Not applicable.

Data Availability Statement: The raw data supporting the conclusions of this manuscript has been submitted to GenBank and will be made available by the authors, without undue reservation, to any qualified researcher.

Conflicts of Interest: The authors declare no conflict of interest.

\section{References}

1. Webster, R.G.; Bean, W.J.; Gorman, O.T.; Chambers, T.M.; Kawaoka, Y. Evolution and ecology of influenza A viruses. Microbiol. Rev. 1992, 56, 152-179. [CrossRef] [PubMed]

2. Gao, R.; Cao, B.; Hu, Y.; Feng, Z.; Wang, D.; Hu, W.; Chen, J.; Jie, Z.; Qiu, H.; Xu, K.; et al. Human infection with a novel avian-origin influenza A (H7N9) virus. N. Engl. J. Med. 2013, 368, 1888-1897. [CrossRef] [PubMed]

3. Gilbert, M.; Chaitaweesub, P.; Parakamawongsa, T.; Premashthira, S.; Tiensin, T.; Kalpravidh, W.; Wagner, H.; Slingenbergh, J. Free-grazing ducks and highly pathogenic avian influenza, Thailand. Emerg. Infect. Dis. 2006, 12, 227-234. [CrossRef] [PubMed]

4. Liu, D.; Shi, W.; Shi, Y.; Wang, D.; Xiao, H.; Li, W.; Bi, Y.; Wu, Y.; Li, X.; Yan, J.; et al. Origin and diversity of novel avian influenza A H7N9 viruses causing human infection: Phylogenetic, structural, and coalescent analyses. Lancet 2013, 381, 1926-1932. [CrossRef]

5. Barman, S.; Marinova-Petkova, A.; Hasan, M.K.; Akhtar, S.; El-Shesheny, R.; Turner, J.C.; Franks, J.; Walker, D.; Seiler, J.; Friedman, K.; et al. Role of domestic ducks in the emergence of a new genotype of highly pathogenic H5N1 avian influenza A viruses in Bangladesh. Emerg. Microbes Infect. 2017, 6, e72. [CrossRef]

6. El-Shesheny, R.; Barman, S.; Feeroz, M.M.; Hasan, M.K.; Jones-Engel, L.; Franks, J.; Turner, J.; Seiler, P.; Walker, D.; Friedman, K.; et al. Genesis of Influenza A(H5N8) Viruses. Emerg. Infect. Dis. 2017, 23, 1368-1371. [CrossRef] 
7. Islam, M.R.; Haque, M.E.; Giasuddin, M.; Chowdhury, E.H.; Samad, M.A.; Parvin, R.; Nooruzzaman, M.; Rahman, M.M.; Monoura, P. New introduction of clade 2.3.2.1 avian influenza virus (H5N1) into Bangladesh. Transbound. Emerg. Dis. 2012, 59, 460-463. [CrossRef]

8. Marinova-Petkova, A.; Feeroz, M.M.; Rabiul Alam, S.M.; Kamrul Hasan, M.; Akhtar, S.; Jones-Engel, L.; Walker, D.; McClenaghan, L.; Rubrum, A.; Franks, J.; et al. Multiple introductions of highly pathogenic avian influenza H5N1 viruses into Bangladesh. Emerg. Microbes Infect. 2014, 3, e11. [CrossRef]

9. Barman, S.; Turner, J.C.M.; Hasan, M.K.; Akhtar, S.; El-Shesheny, R.; Franks, J.; Walker, D.; Seiler, P.; Friedman, K.; Kercher, L.; et al. Continuing evolution of highly pathogenic H5N1 viruses in Bangladeshi live poultry markets. Emerg. Microbes Infect. 2019, 8, 650-661. [CrossRef]

10. El-Shesheny, R.; Franks, J.; Turner, J.; Seiler, P.; Walker, D.; Friedman, K.; Mukherjee, N.; Kercher, L.; Hasan, M.K.; Feeroz, M.M.; et al. Continued Evolution of H5Nx Avian Influenza Viruses in Bangladeshi Live Poultry Markets: Pathogenic Potential in Poultry and Mammalian Models. J. Virol. 2020, 94, e01141-20. [CrossRef]

11. World Health Organization. Antigenic and Genetic Characteristics of Zoonotic Influenza A Viruses and Development of Candidate Vaccine Viruses for Pandemic Preparedness. 2021. Available online: https://cdn.who.int/media/docs/defaultsource/influenza/who-influenza-recommendations/vcm-southern-hemisphere-recommendation-2022/202110_zoonotic_ vaccinevirusupdate.pdf?sfvrsn=8f87a5f1_11 (accessed on 12 November 2021).

12. Peacock, T.H.P.; James, J.; Sealy, J.E.; Iqbal, M. A Global Perspective on H9N2 Avian Influenza Virus. Viruses 2019, 11, 620. [CrossRef]

13. Shanmuganatham, K.; Feeroz, M.M.; Jones-Engel, L.; Smith, G.J.; Fourment, M.; Walker, D.; McClenaghan, L.; Alam, S.M.; Hasan, M.K.; Seiler, P.; et al. Antigenic and molecular characterization of avian influenza A(H9N2) viruses, Bangladesh. Emerg. Infect. Dis. 2013, 19, 1393. [CrossRef]

14. Turner, J.C.; Feeroz, M.M.; Hasan, M.K.; Akhtar, S.; Walker, D.; Seiler, P.; Barman, S.; Franks, J.; Jones-Engel, L.; McKenzie, P.; et al. Insight into live bird markets of Bangladesh: An overview of the dynamics of transmission of H5N1 and H9N2 avian influenza viruses. Emerg. Microbes Infect. 2017, 6, 1-8. [CrossRef]

15. Negovetich, N.J.; Feeroz, M.M.; Jones-Engel, L.; Walker, D.; Alam, S.M.; Hasan, K.; Seiler, P.; Ferguson, A.; Friedman, K.; Barman, S.; et al. Live bird markets of Bangladesh: H9N2 viruses and the near absence of highly pathogenic H5N1 influenza. PLoS ONE 2011, 6, e19311. [CrossRef]

16. World Health Organization. Manual on Animal Influenza Diagnosis and Surveillance. 2nd ed. 2002. Available online: http:/ / whqlibdoc.who.int/hq/2002/WHO_CDS_CSR_NCS_2002.5.pdf (accessed on 10 April 2021).

17. World Organization for Animal Health OIE. Manual of Diagnostic Tests and Vaccines for Terrestrial Animals. Available online: https://www.oie.int/en/what-we-do/standards/codes-and-manuals/terrestrial-manual-online-access/ (accessed on 10 April 2021).

18. Hall, T. BioEdit: A user-friendly biological sequence alignment editor and analysis program for Windows 95/98/NT. Nucleic Acids Symp. Ser. 1999, 41, 95-98.

19. Thompson, J.D.; Higgins, D.G.; Gibson, T.J. CLUSTAL W: Improving the sensitivity of progressive multiple sequence alignment through sequence weighting, position-specific gap penalties and weight matrix choice. Nucleic Acids Res. 1994, 22, 4673-4680. [CrossRef]

20. Kumar, S.; Stecher, G.; Tamura, K. MEGA7: Molecular Evolutionary Genetics Analysis Version 7.0 for Bigger Datasets. Mol. Biol. Evol. 2016, 33, 1870-1874. [CrossRef]

21. El-Shesheny, R.; Feeroz, M.M.; Krauss, S.; Vogel, P.; McKenzie, P.; Webby, R.J.; Webster, R.G. Replication and pathogenic potential of influenza A virus subtypes H3, H7, and H15 from free-range ducks in Bangladesh in mammals. Emerg. Microbes Infect. 2018, 7, 70. [CrossRef]

22. Horimoto, T.; Kawaoka, Y. Reverse genetics provides direct evidence for a correlation of hemagglutinin cleavability and virulence of an avian influenza A virus. J. Virol. 1994, 68, 3120-3128. [CrossRef]

23. Veits, J.; Weber, S.; Stech, O.; Breithaupt, A.; Graber, M.; Gohrbandt, S.; Bogs, J.; Hundt, J.; Teifke, J.P.; Mettenleiter, T.C.; et al. Avian influenza virus hemagglutinins $\mathrm{H} 2, \mathrm{H} 4, \mathrm{H} 8$, and $\mathrm{H} 14$ support a highly pathogenic phenotype. Proc. Natl. Acad. Sci. USA 2012, 109, 2579-2584. [CrossRef]

24. Senne, D.A.; Panigrahy, B.; Kawaoka, Y.; Pearson, J.E.; Süss, J.; Lipkind, M.; Kida, H.; Webster, R.G. Survey of the hemagglutinin (HA) cleavage site sequence of H5 and H7 avian influenza viruses: Amino acid sequence at the HA cleavage site as a marker of pathogenicity potential. Avian Dis. 1996, 40, 425-437. [CrossRef]

25. Wan, H.; Sorrell, E.M.; Song, H.; Hossain, M.J.; Ramirez-Nieto, G.; Monne, I.; Stevens, J.; Cattoli, G.; Capua, I.; Chen, L.M.; et al. Replication and transmission of H9N2 influenza viruses in ferrets: Evaluation of pandemic potential. PLoS ONE 2008, 3, e2923. [CrossRef]

26. Li, X.; Shi, J.; Guo, J.; Deng, G.; Zhang, Q.; Wang, J.; He, X.; Wang, K.; Chen, J.; Li, Y.; et al. Genetics, receptor binding property, and transmissibility in mammals of naturally isolated H9N2 Avian Influenza viruses. PLoS Pathog. 2014, 10, e1004508. [CrossRef]

27. Katz, J.M.; Lu, X.; Tumpey, T.M.; Smith, C.B.; Shaw, M.W.; Subbarao, K. Molecular correlates of influenza A H5N1 virus pathogenesis in mice. J. Virol. 2000, 74, 10807-10810. [CrossRef] 
28. Li, J.; Ishaq, M.; Prudence, M.; Xi, X.; Hu, T.; Liu, Q.; Guo, D. Single mutation at the amino acid position 627 of PB2 that leads to increased virulence of an $\mathrm{H} 5 \mathrm{~N} 1$ avian influenza virus during adaptation in mice can be compensated by multiple mutations at other sites of PB2. Virus Res. 2009, 144, 123-129. [CrossRef]

29. Yamaji, R.; Yamada, S.; Le, M.Q.; Li, C.; Chen, H.; Qurnianingsih, E.; Nidom, C.A.; Ito, M.; Sakai-Tagawa, Y.; Kawaoka, Y. Identification of PB2 mutations responsible for the efficient replication of H5N1 influenza viruses in human lung epithelial cells. J. Virol. 2015, 89, 3947-3956. [CrossRef]

30. Hulse-Post, D.J.; Franks, J.; Boyd, K.; Salomon, R.; Hoffmann, E.; Yen, H.L.; Webby, R.J.; Walker, D.; Nguyen, T.D.; Webster, R.G. Molecular changes in the polymerase genes (PA and PB1) associated with high pathogenicity of H5N1 influenza virus in mallard ducks. J. Virol. 2007, 81, 8515-8524. [CrossRef]

31. Schmolke, M.; Manicassamy, B.; Pena, L.; Sutton, T.; Hai, R.; Varga, Z.T.; Hale, B.G.; Steel, J.; Perez, D.R.; Garcia-Sastre, A. Differential contribution of PB1-F2 to the virulence of highly pathogenic H5N1 influenza A virus in mammalian and avian species. PLoS Pathog. 2011, 7, e1002186. [CrossRef]

32. Subbarao, E.K.; London, W.; Murphy, B.R. A single amino acid in the PB2 gene of influenza A virus is a determinant of host range. J. Virol. 1993, 67, 1761-1764. [CrossRef]

33. Gao, Y.; Zhang, Y.; Shinya, K.; Deng, G.; Jiang, Y.; Li, Z.; Guan, Y.; Tian, G.; Li, Y.; Shi, J.; et al. Identification of amino acids in HA and PB2 critical for the transmission of H5N1 avian influenza viruses in a mammalian host. PLoS Pathog. 2009, 5, e1000709. [CrossRef]

34. Xiao, C.; Ma, W.; Sun, N.; Huang, L.; Li, Y.; Zeng, Z.; Wen, Y.; Zhang, Z.; Li, H.; Li, Q.; et al. PB2-588 V promotes the mammalian adaptation of H10N8, H7N9 and H9N2 avian influenza viruses. Sci. Rep. 2016, 6, 19474. [CrossRef] [PubMed]

35. Conenello, G.M.; Zamarin, D.; Perrone, L.A.; Tumpey, T.; Palese, P. A single mutation in the PB1-F2 of H5N1 (HK/97) and 1918 influenza A viruses contributes to increased virulence. PLoS Pathog. 2007, 3, 1414-1421. [CrossRef] [PubMed]

36. Yamayoshi, S.; Yamada, S.; Fukuyama, S.; Murakami, S.; Zhao, D.; Uraki, R.; Watanabe, T.; Tomita, Y.; Macken, C.; Neumann, G.; et al. Virulence-affecting amino acid changes in the PA protein of H7N9 influenza A viruses. J. Virol. 2014, 88, 3127-3134. [CrossRef] [PubMed]

37. Maines, T.R.; Chen, L.M.; Van Hoeven, N.; Tumpey, T.M.; Blixt, O.; Belser, J.A.; Gustin, K.M.; Pearce, M.B.; Pappas, C.; Stevens, J.; et al. Effect of receptor binding domain mutations on receptor binding and transmissibility of avian influenza H5N1 viruses. Virology 2011, 413, 139-147. [CrossRef]

38. Chutinimitkul, S.; van Riel, D.; Munster, V.J.; van den Brand, J.M.; Rimmelzwaan, G.F.; Kuiken, T.; Osterhaus, A.D.; Fouchier, R.A.; de Wit, E. In Vitro assessment of attachment pattern and replication efficiency of H5N1 influenza A viruses with altered receptor specificity. J. Virol. 2010, 84, 6825-6833. [CrossRef]

39. Wan, H.; Perez, D.R. Amino acid 226 in the hemagglutinin of H9N2 influenza viruses determines cell tropism and replication in human airway epithelial cells. J. Virol. 2007, 81, 5181-5191. [CrossRef]

40. Auewarakul, P.; Suptawiwat, O.; Kongchanagul, A.; Sangma, C.; Suzuki, Y.; Ungchusak, K.; Louisirirotchanakul, S.; Lerdsamran, H.; Pooruk, P.; Thitithanyanont, A.; et al. An avian influenza H5N1 virus that binds to a human-type receptor. J. Virol. 2007, 81, 9950-9955. [CrossRef]

41. Ilyushina, N.A.; Seiler, J.P.; Rehg, J.E.; Webster, R.G.; Govorkova, E.A. Effect of neuraminidase inhibitor-resistant mutations on pathogenicity of clade 2.2 A/Turkey/15/06 (H5N1) influenza virus in ferrets. PLoS Pathog. 2010, 6, e1000933. [CrossRef]

42. Sleeman, K.; Guo, Z.; Barnes, J.; Shaw, M.; Stevens, J.; Gubareva, L.V. R292K substitution and drug susceptibility of influenza A(H7N9) viruses. Emerg. Infect. Dis. 2013, 19, 1521-1524. [CrossRef]

43. Abed, Y.; Goyette, N.; Boivin, G. Generation and characterization of recombinant influenza A (H1N1) viruses harboring amantadine resistance mutations. Antimicrob. Agents Chemother. 2005, 49, 556-559. [CrossRef]

44. Bean, W.J.; Threlkeld, S.C.; Webster, R.G. Biologic potential of amantadine-resistant influenza A virus in an avian model. J. Infect. Dis. 1989, 159, 1050-1056. [CrossRef]

45. Cheung, C.L.; Rayner, J.M.; Smith, G.J.; Wang, P.; Naipospos, T.S.; Zhang, J.; Yuen, K.Y.; Webster, R.G.; Peiris, J.S.; Guan, Y.; et al. Distribution of amantadine-resistant H5N1 avian influenza variants in Asia. J. Infect. Dis. 2006, 193, 1626-1629. [CrossRef]

46. Jiao, P.; Tian, G.; Li, Y.; Deng, G.; Jiang, Y.; Liu, C.; Liu, W.; Bu, Z.; Kawaoka, Y.; Chen, H. A single-amino-acid substitution in the NS1 protein changes the pathogenicity of H5N1 avian influenza viruses in mice. J. Virol. 2008, 82, 1146-1154. [CrossRef]

47. Seo, S.H.; Hoffmann, E.; Webster, R.G. Lethal H5N1 influenza viruses escape host anti-viral cytokine responses. Nat. Med. 2002, 8, 950-954. [CrossRef]

48. Li, Z.; Jiang, Y.; Jiao, P.; Wang, A.; Zhao, F.; Tian, G.; Wang, X.; Yu, K.; Bu, Z.; Chen, H. The NS1 gene contributes to the virulence of H5N1 avian influenza viruses. J. Virol. 2006, 80, 11115-11123. [CrossRef]

49. Stallknecht, D.E.; Luttrell, M.P.; Poulson, R.; Goekjian, V.; Niles, L.; Dey, A.; Krauss, S.; Webster, R.G. Detection of avian influenza viruses from shorebirds: Evaluation of surveillance and testing approaches. J. Wildl. Dis. 2012, 48, 382-393. [CrossRef]

50. Han, J.; Wang, L.; Liu, J.; Jin, M.; Hao, F.; Zhang, P.; Zhang, Z.; Wen, D.; Wu, X.; Liu, G.; et al. Cocirculation of three hemagglutinin and two neuraminidase subtypes of avian influenza viruses in Huzhou, China, April 2013: Implication for the origin of the novel H7N9 virus. J. Virol. 2014, 88, 6506-6511. [CrossRef]

51. Parvin, R.; Nooruzzaman, M.; Kabiraj, C.K.; Begum, J.A.; Chowdhury, E.H.; Islam, M.R.; Harder, T. Controlling Avian Influenza Virus in Bangladesh: Challenges and Recommendations. Viruses 2020, 12, 751. [CrossRef] 